\title{
DESAIN PRODUK BANLEY (BARCODE SCANNER TROLLEY) TERHADAP FLEKSIBILITAS LAYANAN PEMBELIAN PRODUK
}

\author{
Rausan Fikri Arman ${ }^{1}$, Fauzan Aufa Mahsa Arifin², Muhammad Firdaus Kamal ${ }^{3}$, I Komang Kusuma Putra ${ }^{4}$, dan \\ Farida Pulansari ${ }^{5}$ \\ 1,2,3 Department of Environmental Engineering, University of Pembangunan Nasional "Veteran" Jawa Timur, \\ Raya Rungkut Madya, Surabaya 60294, Indonesia, Phone: (+62-031) 8782179, Fax. (+62-031) 8782257 \\ ${ }^{4.5}$ Department of Industrial Engineering, University of Pembangunan Nasional "Veteran" Jawa Timur, Raya \\ Rungkut Madya, Surabaya 60294, Indonesia, Phone: (+62-031) 8782179, Fax. (+62-031) 8782257
}

\begin{abstract}
ABSTRAK
Berubahnya pola belanja dan tingkat konsumerisme masyarakat dari pasar tradisional ke pasar modern telah memberikan ruang terhadap usaha ritel dewasa ini. Usaha ritel melayani pembelian dalam jumlah kecil maupun besar (grosir) dengan berbagai segmen pasar, strategi pemasaran yang tepat, potongan harga serta tempat berbelanja yang nyaman telah memberikan daya tarik tersendiri bagi masyarakat. Dengan pola belanja yang berubah maka tidak jarang kita lihat antrian pada kasir di waktu-waktu tertentu. Terkadang masalah lain juga muncul yaitu tidak sesuainya antara produk yang dijual dengan label yang ditempel pada rak. Disisi lain, papan promosi atau diskon juga tidak sesuai, sehingga membingungkan pembeli. Berdasarkan permasalahan tersebut, diciptakanlah BANLEY (Barcode Scanner Trolley). BANLEY merupakan trolley belanja pintar yang dapat mengidentifikasi harga secara langsung, memiliki sensor berat yang bekerja real time serta dilengkapi dengan fitur keterangan produk, harga satuan, total harga yang harus dibayarkan ke kasir dan berat produk secara keseluruhan. Berdasarkan kuesioner yang telah disebar pada 150 responden dengan 3 variabel yang penilaian yaitu keandalan, empati, serta kepuasaan pelanggan, hasilnya valid dan reliabel dengan nilai Cronbach Alpha $>0.60$.
\end{abstract}

Kata kunci: Barcode Scanner Trolley, Ritel, Berat.

\section{PENDAHULUAN}

Pasar Modern (Supermarket) adalah pasar yang dikelola dengan manajemen modern yang pada umumnya terdapat di daerah perkotaan sebagai penyedia barang dan jasa dengan mutu dan pelayanan yang baik kepada konsumen. Jenis-jenis pasar modern antara lain supermarket, mall, department store, shopping centre, toko mini swalayan, toko serba ada, waralaba, pasar serba ada, dan sebagainya (Sinaga, 2008). Menurut Koentjaraningrat (2009) swalayan (Supermarket) dirancang untuk melayani semua kebutuhan konsumen seperti produk bahan makanan dan peralatan rumah tangga.

Menurut Direktur Jenderal Perdagangan Dalam Negeri Kemendag Srie Agustina pada tahun 2014, di seluruh Indonesia jumlah pasar modern mencapai 23.000 unit toko yang terdiri dari 14.000 kelompok usaha minimarket dan 9.000 supermarket, jumlah ini terjadi peningkatan sebesar 14 persen sejak tahun 2011 hingga 2014 (Jannah, 2014). Pasar modern memiliki beberapa kelebihan dibandingkan dengan pasar tradisional, antaralain kualitas produk dan pelayanan, lokasi yang nyaman, iklan dan promosi, desain dan lingkungan gerai, dan tambahan pengetahuan (Indiastuti dkk., 2008). Hal ini lah menjadikan pasar modern lebih diminati masyarakat dibandingkan pasar tradisional.

Namun pasar modern juga memiliki kelemahan, antara lain kesulitan dalam mengetahui informasi penting seperti barang yang sedang diskon, promosi swalayan, dan syarat promosi yang berlaku (Mufida, dkk., 2016). Masalah lainnya adalah ketika harga yang tertera pada label tidak sama 
dengan harga di kasir. Hal ini akan sangat menganggu konsumen karena tidak dapat memperkirakan biaya yang dikeluarkan dengan uang yang dimiliki.

Berdasarkan permasalahan tersebut muncul sebuah ide untuk membuat suatu teknologi barcode scanner trolley (BANLEY). Sistem ini menyediakan pemindaian produk dan menunjukkan rincian harga pada LCD. Hal ini memungkinkan pelanggan untuk membandingkan harga total belanja dengan anggaran belanja yang dimiliki oleh pelanggan.

\section{METODE}

Penelitian dilaksanakan pada bulan Maret hingga Juni 2018. Pada gambar 1 dapat dilihat diagram alir BANLEY.

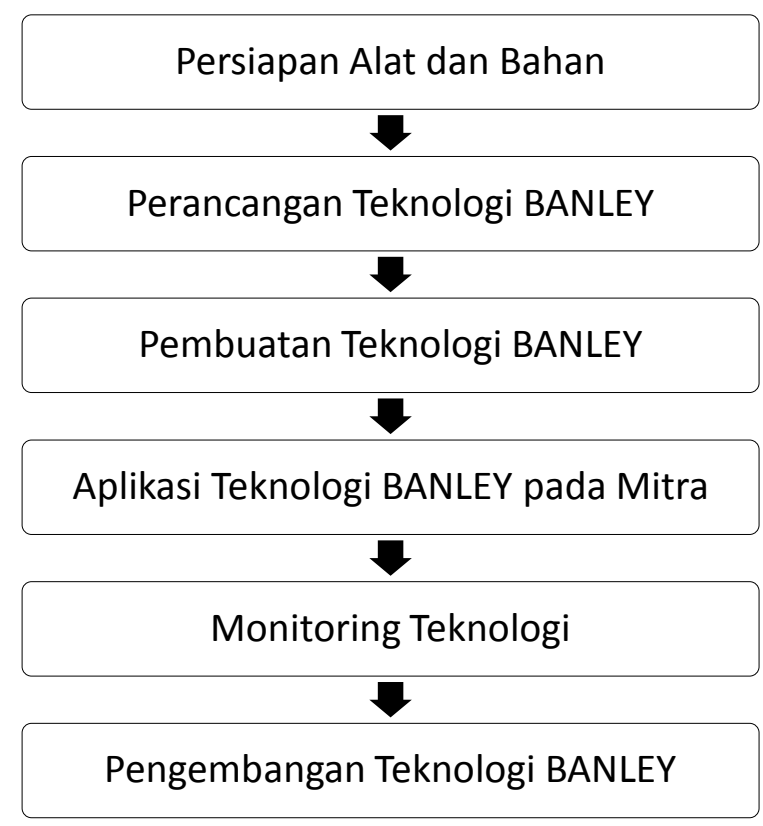

Gambar 1. Diagram Alir BANLEY

\subsection{Deskripsi Pelaksanaan}

\subsubsection{Persiapan Alat dan Bahan}

Alat dan bahan yang diperlukan untuk membuat teknologi BANLEY seperti perlengkapan pada barcode scanner, battery Li-Poly, dan microcontroller.

\subsubsection{Rancang Bangun Teknologi BANLEY}

Pada tahap ini akan dibuat rancangan teknologi BANLEY yang sesuai dengan substansi permasalahan mitra. Sistem teknologi BANLEY dirancang dengan cara menempatkan barcode scanner pada trolley belanjaan yang berfungsi untuk men-scan barcode yang ada pada barang-barang yang akan dibeli oleh pembeli. Untuk menampilkan display barang belanjaan yang di scan diperlukan LCD berukuran $16 \times 4$ yang nantinya menampilkan nama barang belanjaan yang di scan. Sumber tenaga yang digunakan untuk menjalankan rangkaian elektronik tersebut menggunakan battery Li-Poly, selain itu dibutuhkan juga microcontroller Genuino/Arduino 101 sebagai pengontrol rangkaian eletronik pada teknologi BANLEY. Untuk mengurangi kecurangan yang dilakukan oleh pembeli, dipasang strain gauge pada trolley yang nantinya akan menimbang berat total barang belanja dengan toleransi kesalahan $0,02 \%$. 


\subsubsection{Pembuatan Teknologi BANLEY}

Langkah-langkah pembuatan sistem teknologi BANLEY diantaranya:

1. Mengalibrasi semua komponen

2. Merancang program

3. Melakukan pengujian program pada hardware

4. Pemasangan Genuino/Arduino 101

5. Pemasangan Barcode scanner, LCD $16 \times 4$, Strain gauge

6. Pemasangan battery Li-Poly sebagai sumber energi

\subsubsection{Penerapan atau Aplikasi pada Mitra}

Pada tahap ini dilakukan penerapan teknologi BANLEY secara langsung pada mitra. Hal ini bertujuan untuk mengetahui tingkat keefektifan teknologi BANLEY dalam menyelesaikan permasalahan mitra. Guna mengukur tingkat keberhasilan penerapan teknologi ini, digunakan kuisioner yang ditujukan kepada mitra dan pelanggan swalayan. Diharapkan dengan diterapkannya teknologi BANLEY ini, dapat menyelesaikan permasalahan yang dihadapi oleh mitra.

\subsubsection{Monitoring Teknologi BANLEY}

Pada tahap ini akan dilakukan pemantauan dan pemeriksaan secara berkala untuk menjaga performa/kinerja teknologi BANLEY agar tetap baik.

\subsubsection{Pengembangan Teknologi BANLEY}

Pada tahap ini akan dilakukan pembahasan dengan mitra terkait dengan pengembangan teknologi BANLEY ke depannya. Desain dan Perancangan 'BANLEY' ditunjukkan pada Gambar 2.

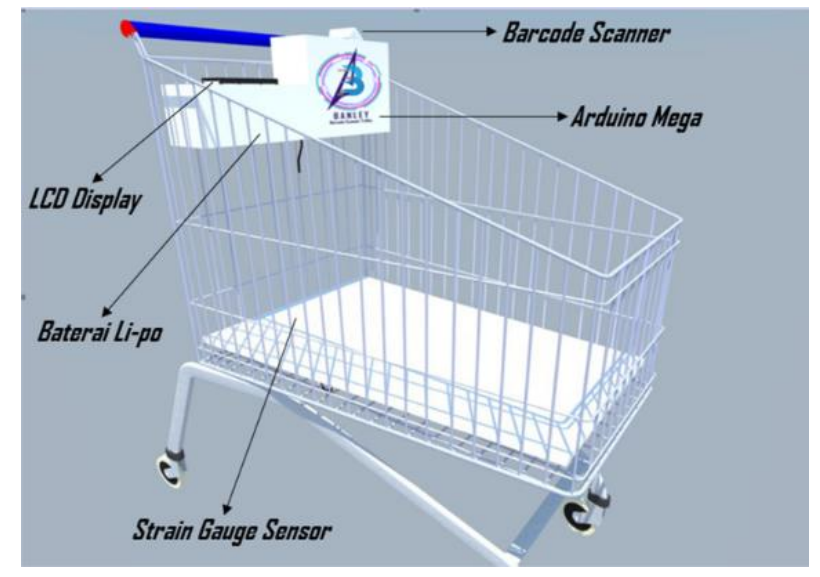

Gambar 2. Desain 3D BANLEY

Rancang bangun pertama adalah melakukan sinkronisasi antara barcode scanner dengan Arduino. Arduino adalah platform elektronik open source yang dapat membaca input (sensor dan fungsi tombol) dan mengubahnya menjadi output (mengaktifkan motor dan menyalakan LED). Arduino dapat berfungsi jika satu set instruksi ke mikrokontroler pada board Arduino telah diprogram sebelumnya dengan bahasa pemrograman Arduino (Wiring) dan Arduino Software (IDE) (Aslamia, 2015). Perangkat barcode scanner disambungkan pada Arduino, kemudian ditanamkan program pada mikrokontroler agar rangkaian elektronik dapat membaca input, memproses input, 
dan menghasilkan output seperti yang diinginkan. Hasil output nantinya akan ditampilkan pada layar LCD.

Tahap kedua yaitu melakukan sinkronisasi antara sensor berat (Strain gauge) dengan Arduino. Strain gauge adalah komponen elektronika yang digunakan untuk mengukur tekanan (deformasi atau strain). Strain gauge berbentuk foil logam atau kawat logam yang bersifat insulatif (isolasi) yang ditempelkan pada benda yang akan diukur tekanannya yang berasal dari pembebanan (Boyes, 2009). Selain itu juga dilakukan pengujian dengan metode kuesioner untuk mengetahui bagaimana respon dari masyarakat khususnya pengunjung supermarket yang telah mencoba barcode scanner trolley ini. Pada Gambar 3 dan 4 merupakan hasil visual tampilan LCD BANLEY dan LCD pada layar Kasir yang menunjukkan total harga yang sama.
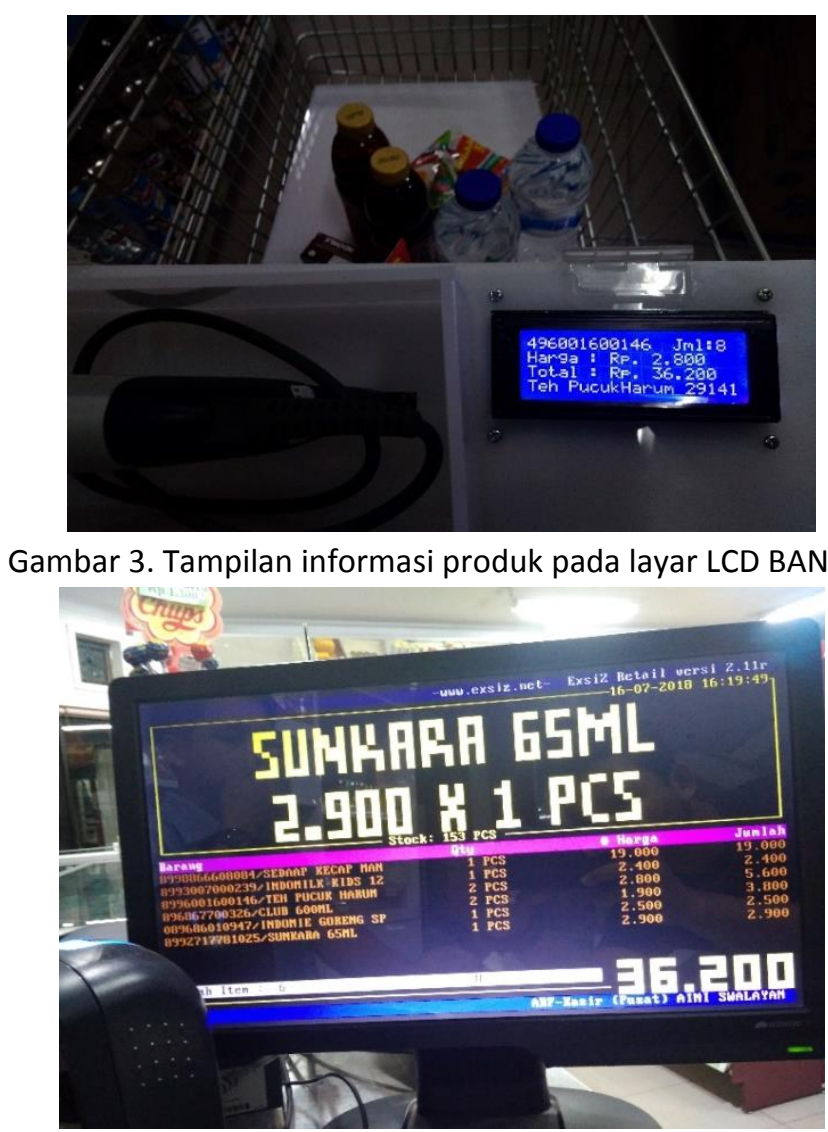

Gambar 4. Tampilan layar komputer kasir supermarket

\subsection{Instrumen Pengujian BANLEY}

Pengukuran tingkat keberhasilan teknologi ini diuji dengan kuisioner. Variabel independen yang digunakan adalah Keandalan $\left(\mathrm{X}_{1}\right)$ dan Empati $\left(\mathrm{X}_{2}\right)$. Variabel dependen yang digunakan adalah Kepuasan Pelanggan ( $\mathrm{Y}$ ).

\section{HASIL DAN PEMBAHASAN}

Berikut ini akan dilakukan beberapa uji statistik terhadap konsumen yang menggunakan BANLEY

\subsection{Kuesioner}

\subsubsection{Karakteristik Responden}


Responden adalah masyarakat umum yang berbelanja di Aini Swalayan. Jumlah kuesioner yang disebar sebanyak 150 orang responden. Karakteristik responden diidentifikasi berdasarkan jenis kelamin, usia, seberapa sering ke swalayan dalam seminggu, pekerjaan, dan penghasilan per bulan. Pada gambar 5 disajikan mengenai rincian penyebaran kuesioner.

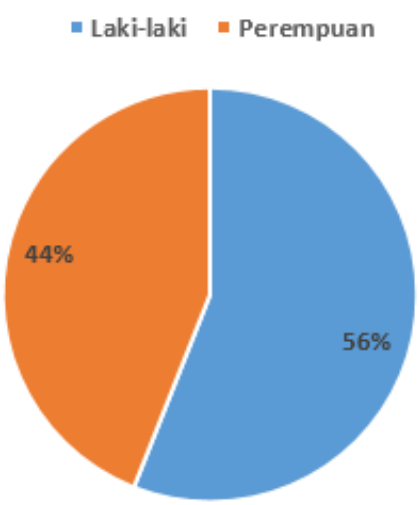

(a)

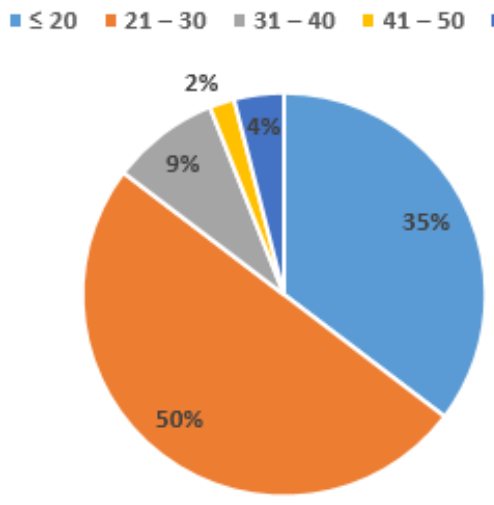

(b)

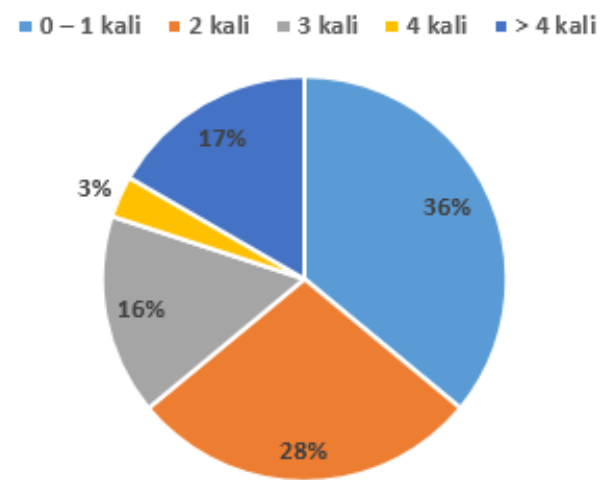

(c)

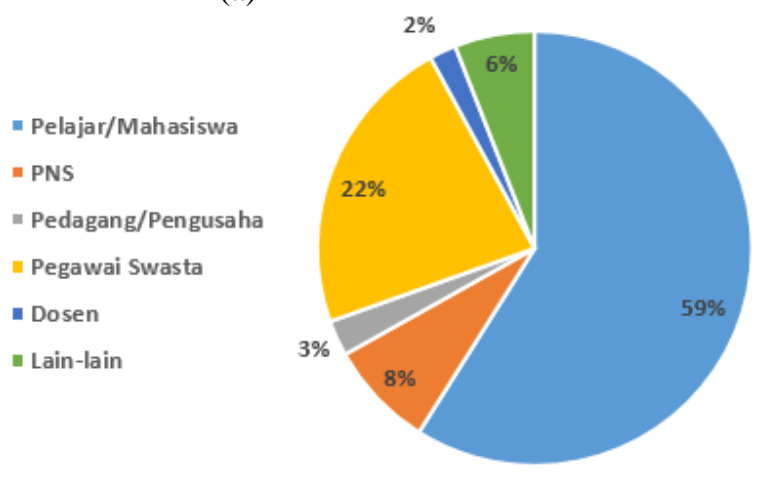

(d)

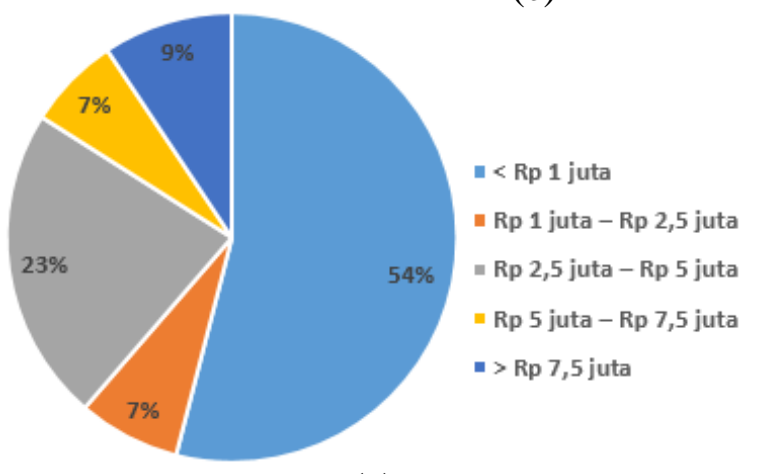

(e)

Gambar 5. Identifikasi responden berdasarkan:

(a) jenis kelamin, (b) usia, (c) seberapa sering ke swalayan dalam seminggu,

(d) pekerjaan, (e) penghasilan per bulan

\subsubsection{Hasil Pengujian BANLEY}

Pada tabel 1 menggambarkan tanggapan responden terhadap variabel keandalan $\left(X_{1}\right)$

Tabel 1. Tanggapan Responden Variabel Keandalan $\left(X_{1}\right)$

\begin{tabular}{|c|c|c|c|c|c|c|}
\hline \multirow{2}{*}{ Item } & \multicolumn{7}{|c|}{ Skor } \\
\cline { 2 - 7 } & $\begin{array}{c}\text { STS } \\
(\mathbf{1})\end{array}$ & $\begin{array}{c}\text { TS } \\
\mathbf{( 2 )}\end{array}$ & $\begin{array}{c}\mathbf{N} \\
\mathbf{( 3 )}\end{array}$ & $\begin{array}{c}\text { S } \\
\mathbf{( 4 )}\end{array}$ & $\begin{array}{c}\text { SS } \\
\text { (5) }\end{array}$ & \multirow{2}{*}{ Mean } \\
\hline 1 & 0 & 1 & 34 & 70 & 45 & 4,06 \\
\hline 2 & 0 & 1 & 21 & 53 & 75 & 4,35 \\
\hline 3 & 0 & 0 & 14 & 64 & 72 & 4,39 \\
\hline Jumlah & 0 & 2 & 69 & 187 & 192 & \\
\hline Persentase (\%) & 0 & 0,44 & 15,33 & 41,56 & 42,67 & \\
\hline
\end{tabular}

Pada tabel 2 menggambarkan tanggapan responden terhadap variabel empati $\left(\mathrm{X}_{2}\right)$. Tabel 2. Tanggapan Responden Variabel Empati $\left(\mathrm{X}_{2}\right)$

\begin{tabular}{|c|c|c|c|c|c|c|}
\hline \multirow[b]{2}{*}{ Item } & \multicolumn{6}{|c|}{ Skor } \\
\hline & $\begin{array}{l}\text { STS } \\
\text { (1) }\end{array}$ & $\begin{array}{l}\text { TS } \\
\text { (2) }\end{array}$ & $\begin{array}{l}N \\
\text { (3) }\end{array}$ & $\begin{array}{c}S \\
(4)\end{array}$ & $\begin{array}{l}\text { SS } \\
\text { (5) }\end{array}$ & Mean \\
\hline 1 & 0 & 1 & 14 & 64 & 71 & 4,37 \\
\hline 2 & 0 & 4 & 15 & 64 & 67 & 4,29 \\
\hline
\end{tabular}




\begin{tabular}{|c|c|c|c|c|c|c|}
\hline 3 & 0 & 0 & 8 & 58 & 84 & 4,51 \\
\hline Jumlah & 0 & 5 & 37 & 186 & 222 & \\
\hline Persentase (\%) & 0 & 1,11 & 8,22 & 41,33 & 49,33 & \\
\hline
\end{tabular}
(Y).

Pada tabel 3 menggambarkan tanggapan responden terhadap variabel kepuasan pelanggan

Tabel 3. Tanggapan Responden Variabel Kepuasan Pelanggan (Y)

\begin{tabular}{|c|c|c|c|c|c|c|}
\hline \multirow{2}{*}{ Item } & \multicolumn{7}{|c|}{ Skor } \\
\cline { 2 - 7 } & $\begin{array}{c}\text { STS } \\
(\mathbf{1})\end{array}$ & $\begin{array}{c}\text { TS } \\
\mathbf{( 2 )}\end{array}$ & $\begin{array}{c}\mathbf{N} \\
\mathbf{( 3 )}\end{array}$ & $\begin{array}{c}\mathbf{S} \\
\mathbf{( 4 )}\end{array}$ & $\begin{array}{c}\text { SS } \\
\mathbf{( 5 )}\end{array}$ & \multirow{2}{*}{ Mean } \\
\hline 1 & 1 & 5 & 43 & 64 & 37 & 3,87 \\
\hline 2 & 1 & 4 & 38 & 69 & 38 & 3,93 \\
\hline 3 & 0 & 0 & 20 & 71 & 59 & 4,26 \\
\hline Jumlah & 2 & 9 & 101 & 204 & 134 & \\
\hline Persentase (\%) & 0,44 & 2 & 22,44 & 45,33 & 29,78 & \\
\hline
\end{tabular}

\subsection{Instrumen Pengujian}

\subsubsection{Uji Validitas}

Uji validitas dilakukan dengan program SPSS, dengan kriteria sebagai berikut:

1. Nilai $r$ hitung dapat dilihat pada kolom corrected item total correlation.

2. Jika $r$ hitung $>r$ tabel maka item dinyatakan valid.

3. Jika $r$ hitung $<r$ tabel maka item dinyatakan tidak valid.

Total responden berjumlah 150 orang, sehingga diperoleh $r$ tabel yaitu 0,1348. Hasil uji validitas instrumen dari ketiga variabel pada tabel 4 menunjukkan seluruh data yang dikumpulkan semuanya valid, karena nilai Corrected Item-Total Correlation lebih tinggi dari nilai $r$ tabel yaitu 0,1348 .

Tabel 4. Hasil Uji Validitas Instrumen

\begin{tabular}{|l|c|c|c|c|}
\hline \multirow{3}{*}{ Variabel } & Item & $\begin{array}{c}\text { Corrected } \\
\text { Item-Total } \\
\text { Correlation }\end{array}$ & Nilai r tabel & Keterangan \\
\hline \multirow{3}{*}{ Keandalan } & $\mathrm{P} 1$ & 0,817 & 0,1348 & Valid \\
\cline { 2 - 5 } & $\mathrm{P} 2$ & 0,835 & 0,1348 & Valid \\
\cline { 2 - 5 } & $\mathrm{P} 3$ & 0,790 & 0,1348 & Valid \\
\hline \multirow{3}{*}{ Empati } & $\mathrm{P} 1$ & 0,868 & 0,1348 & Valid \\
\cline { 2 - 5 } & $\mathrm{P} 2$ & 0,872 & 0,1348 & Valid \\
\cline { 2 - 5 } & $\mathrm{P} 3$ & 0,800 & 0,1348 & Valid \\
\cline { 2 - 5 } & $\mathrm{P} 1$ & 0,826 & 0,1348 & Valid \\
\cline { 2 - 5 } & $\mathrm{P} 2$ & 0,831 & 0,1348 & Valid \\
\cline { 2 - 5 } & $\mathrm{P} 3$ & 0,517 & 0,1348 & Valid \\
\hline
\end{tabular}

Sumber: pengolahan SPSS (2018)

\subsubsection{Uji Reliabilitas}

Uji reliabilitas dilakukan dengan menguji item yang telah dinyatakan valid dalam uji validitas, penentuan reliabilitas menggunakan program SPSS. Variabel dinyatakan reliabel dengan kriteria sebagai berikut:

1. Variabel dikatakan baik jika memiliki nilai Cronbach's Alpha > dari 0,60

2. Jika r-alpha positif dan lebih besar dari r-tabel maka pernyataan reliabel.

3. Jika r-alpha negatif dan lebih kecil dari r-tabel maka pernyataan tidak reliabel.

Hasil uji reliabiltas dengan menggunakan SPSS adalah sebagai berikut: 
Tabel 5. Hasil Uji Reliabilitas Instrumen

\begin{tabular}{|l|c|l|}
\hline \multicolumn{1}{|c|}{ Variabel } & Cronbach's Alpha & Keterangan \\
\hline Keandalan $\left(\mathrm{X}_{1}\right)$ & 0,832 & Reliabel \\
\hline Empati $\left(\mathrm{X}_{2}\right)$ & 0,845 & Reliabel \\
\hline Kepuasan Pelanggan $(\mathrm{Y})$ & 0,794 & Reliabel \\
\hline
\end{tabular}

Sumber: pengolahan SPSS (2018)

Berdasarkan hasil pengolahan data menggunakan program SPSS, nilai Croanbach Alpha variabel keandalan, empati, dan kepuasan pelanggan lebih dari 0,60 sehingga dapat dikatakan reliabel.

\subsubsection{Uji Normalitas}

Uji normalitas dilakukan untuk mengetahui normal atau tidaknya suatu distribusi data. Pengujian normalitas yang didasarkan pada uji statistik non parametrik Kolmogorof-Smirnov (K-S). Apabila hasil uji Kolmogorov Smirnov, nilai Asymp. Sig. (2-tailed) lebih dari 0,05 $(\alpha=5 \%$ ), maka data berdistribusi normal. Hasil uji normalitas terdapat pada tabel 6.

Tabel 6. Uji Normalitas Kolmogrov-Smirnov One-Sample Kolmogorov-Smirnov Test

\begin{tabular}{|c|c|c|}
\hline \multicolumn{3}{|c|}{ One-Sample Kolmogorov-Smirnov Test } \\
\hline & & $\begin{array}{c}\text { Unstandardized } \\
\text { Residual }\end{array}$ \\
\hline $\mathrm{N}$ & & 150 \\
\hline \multirow[t]{2}{*}{ Normal Parameters ${ }^{a, b}$} & Mean &, 0000000 \\
\hline & Std. Deviation & 1,50252468 \\
\hline \multirow[t]{3}{*}{ Most Extreme Differences } & Absolute & 069 \\
\hline & Positive & ,068 \\
\hline & Negative &,- 069 \\
\hline Test Statistic & & ,069 \\
\hline Asymp. Sig. (2-tailed) & & $076^{\circ}$ \\
\hline
\end{tabular}
a. Test distribution is Normal.
b. Calculated from data.
c. Lilliefors Significance Correction.

Berdasarkan uji statistik normalitas Kolmogrov-Smirnov pada tabel 6, menunjukkan bahwa nilai Asymp. Sig. (2-tailed) adalah 0,076, sehingga melebihi nilai signifikan $(0,05)$. Berdasarkan hal tersebut, maka data berdistribusi normal.

\subsubsection{Uji Parsial (Uji-t)}

Uji t berfungsi untuk menguji pengaruh masing-masing variabel independen (keandalan dan empati) secara sendiri-sendiri terhadap variabel dependen (kepuasan pelanggan), dengan bentuk pengujian sebagai berikut:

$\mathrm{H}_{0}$ : variabel independen secara parsial tidak berpengaruh positif dan signifikan terhadap variabel dependen 
$\mathrm{H}_{1}$ : variabel independen secara parsial berpengaruh positif dan signifikan terhadap variabel dependen

Nilai t hitung akan dibandingkan dengan nilai t tabel. Kriteria pengambilan keputusan yaitu:

t hitung $<$ t tabel pada $\alpha=5 \% \rightarrow \mathrm{H}_{0}$ diterima

t hitung $>\mathrm{t}$ tabel pada $\alpha=5 \% \rightarrow \mathrm{H}_{1}$ diterima

Pada tabel 7 dapat dilihat hasil pengujian kuisioner dengan SPSS. Diketahui nilai $t$ tabel dari 150 sampel dengan 2 variabel $\left(X_{1}\right.$ dan $\left.X_{2}\right)$ adalah $t$ tabel $=1,976$.

Tabel 7. Uji Parsial (Uji-t)

Coefficients $^{\mathrm{a}}$

\begin{tabular}{|c|c|c|c|c|c|c|}
\hline & & \multicolumn{2}{|c|}{ Unstandardized Coefficients } & $\begin{array}{c}\text { Standardized } \\
\text { Coefficients }\end{array}$ & \multirow[t]{2}{*}{$\mathrm{t}$} & \multirow[t]{2}{*}{ Sig. } \\
\hline \multicolumn{2}{|c|}{ Model } & B & Std. Error & Beta & & \\
\hline \multirow[t]{3}{*}{1} & (Constant) & 3,864 & ,981 & & 3,940 & ,000 \\
\hline & $\mathrm{X} 1$ & ,342 & ,086 & ,345 & 3,987 & ,000 \\
\hline & $\mathrm{x} 2$ & ,290 & ,087 & ,289 & 3,346 & ,001 \\
\hline
\end{tabular}

a. Dependent Variable: $Y$

Berdasarkan Tabel 7, diketahui bahwa variabel keandalan $\left(X_{1}\right)$ berpengaruh signifikan terhadap kepuasan pelanggan $(\mathrm{Y})$, berdasarkan nilai signifikan $(0,000<0,05)$ dan nilai t hitung $(3,987$ $>\mathrm{t}$ tabel). Pada variabel empati $\left(\mathrm{X}_{2}\right)$ berpengaruh signifikan terhadap kepuasan pelanggan $(\mathrm{Y})$, berdasarkan nilai signifikan $(0,001<0,05)$ dan nilai t hitung $(3,346>$ t tabel).

\subsubsection{Uji Serentak (Uji-F)}

Uji F (uji serentak) berfungsi untuk menguji pengaruh variabel independen secara bersamasama (serentak) dan signifikan terhadap variabel dependen. Bentuk pengujiannya yaitu:

$\mathrm{H}_{0}$ : secara serentak tidak terdapat pengaruh positif dan signifikan dari variabel independen (keandalan dan empati) terhadap variabel dependen (kepuasan pelanggan).

$\mathrm{H}_{1}$ : secara serentak terdapat pengaruh positif dan signifikan dari variabel independen (keandalan dan empati) terhadap variabel dependen (kepuasan pelanggan).

Nilai $f$ hitung akan dibandingkan dengan nilai $f$ tabel, dengan kriteria pengambilan keputusan yaitu:

f hitung $<\mathrm{f}$ tabel pada $\alpha=5 \% \rightarrow \mathrm{H}_{0}$ diterima

f hitung $>\mathrm{f}$ tabel pada $\alpha=5 \% \rightarrow \rightarrow \mathrm{H}_{1}$ diterima

Hasil perhitungan dengan menggunakan program SPSS dapat dilihat pada tabel 8.

Tabel 8. Uji Serentak (Uji-F)

\begin{tabular}{|c|c|c|c|c|c|c|}
\hline \multicolumn{7}{|c|}{ ANOVA $^{a}$} \\
\hline & & Sum of Squares & df & Mean Square & $\mathrm{F}$ & Sig. \\
\hline \multirow[t]{3}{*}{1} & Regression & 145,815 & 2 & 72,908 & \multirow[t]{3}{*}{35,648} & \multirow[t]{3}{*}{, $000^{\mathrm{b}}$} \\
\hline & Residual & 300,645 & 147 & 2,045 & & \\
\hline & Total & 446,460 & 149 & & & \\
\hline
\end{tabular}

a. Dependent Variable: Kinerja ASN

b. Predictors: (Constant), Promosi, Mutasi

Sumber: pengolahan SPSS (2018)

Hasil pengujian ANOVA dengan menggunakan uji $\mathrm{F}$ pada Tabel 8 memperlihatkan nilai Fhitung sebesar 35,648 dengan Sig 0,000. Jumlah sampel adalah 150 sampel dengan 2 variabel $\left(X_{1}\right.$ dan $\mathrm{X}_{2}$ ), yang mana pada Tabel $\mathrm{F}$ dengan $\mathrm{df} 1=2$ dan $\mathrm{df} 2=148$, diperoleh nilai $\mathrm{F}$-tabel $=3,06$. Kondisi $\mathrm{F}$ hitung yang lebih besar daripada F-tabel $(25,111>3,06)$ dengan nilai Sig 0,000 yang berarti lebih kecil 
dari alpha $(0,000<0,05)$, memberikan arti bahwa secara bersamaan (simultan) variabel variabel keandalan $\left(\mathrm{X}_{1}\right)$ dan empati $\left(\mathrm{X}_{2}\right)$ berpengaruh signifikan terhadap kepuasan pelanggan $(\mathrm{Y})$.

\section{$4 \quad$ KESIMPULAN}

Kesimpulan yang diperoleh adalah :

1. BANLEY merupakan trolley yang dapat memudahkan pengunjung supermarket dalam berbelanja dengan fitur tambahan berupa layar LCD 20x4 yang menampilkan informasi produk mulai dari harga satuan, harga total, kuantitas, dan berat produk.

2. Hasil uji validitas variabel Keandalan, Empati, dan Kepuasan Pelanggan memiliki nilai Corrected Item-Total Correlation yang lebih tinggi dari nilai $r$ tabel yaitu 0,1348 , sehingga menunjukkan data tersebut valid.

3. Hasil Uji Reliabilitas menunjukkan bahwa nilai Croanbach Alpha variabel keandalan, empati, dan kepuasan pelanggan lebih dari 0,6 sehingga jawaban yang diberikan responden dapat dikatakan reliabel.

4. Hasil uji normalitas berdasarkan uji statistik normalitas Kolmogrov-Smirnov menunjukkan bahwa nilai Asymp.sig. (2-tailed) adalah 0,076, sehingga lebih dari nilai signifikan $(0,05)$. Berdasarkan hal tersebut, maka variabel residual berdistribusi normal.

5. Hasil uji parsial (uji-t) diketahui bahwa variabel keandalan $\left(X_{1}\right)$ berpengaruh signifikan terhadap kepuasan pelanggan $(Y)$. Hal ini dapat dilihat dari nilai signifikan $(0,000<0,05)$ dan nilai $t$ hitung $\left(3,987>t\right.$ tabel). Pada variabel empati $\left(X_{2}\right)$ berpengaruh signifikan terhadap kepuasan pelanggan $(Y)$. Hal ini terlihat dari nilai signifikan $(0,001<0,05)$ dan nilai t hitung $(3,346>$ t tabel).

6. Hasil pengujian ANOVA dengan menggunakan uji $F$ memperlihatkan nilai F-hitung sebesar 35,648 dengan Sig 0,000. Jumlah sampel adalah 150 sampel dengan 2 variabel (X1 dan X2), yang mana pada Tabel $F$, dengan df $1=2$ dan $d f 2=148$, diperoleh nilai $F$-tabel $=3,06$. Kondisi $F$ hitung lebih besar daripada F-tabel $(25,111>3,06)$ dengan nilai Sig 0,000 yang berarti lebih kecil dari alpha $(0,000<0,05)$, memberikan arti bahwa secara bersamaan (simultan) variabel variabel keandalan $\left(X_{1}\right)$ dan empati $\left(X_{2}\right)$ berpengaruh signifikan terhadap kepuasan pelanggan (Y).

\section{DAFTAR PUSTAKA}

Aslamia, Suhaybatul, 2015. Robot Pendeteksi Manusia Sebagai Sistem Keamanan Ruangan Menggunakan Sensor Pir Dengan Media Komunikasi XBee Berbasis Arduino Leonardo (Sub Bahasan: Software). Laporan Akhir. Politeknik Negeri Sriwijaya. Palembang.

Boyes, W., 2009. Instrumentation Reference Book. Butterworth-Heinemann. Oxford.

Indiastuti, R., F. Hastuti, dan Y. Azis, 2008. Analisis Keberlanjutan Pasar Tradisional dalam Iklim Persaingan Usaha yang Dinamis di Kota Bandung. Sosiohumaniora, Vol. 10, No. 2, 17-37.

Jannah, K. M., 2014. Pasar Modern Indonesia Tumbuh 14\% dalam 3 Tahun diakses dalam https://economy.okezone.com/read/2014/08/07/320/1021276/pasar-modern-indonesiatumbuh-14-dalam-3-tahun [26 November 2017].

Koentjaraningrat. 2009. Pengantar Ilmu Antropologi. Rineka Cipta. Jakarta

Mufida, M. K., S. Silfia, T. Novianti, Virtual Shopping Assistant. Dipresentasikan pada seminar Applied Business and Engineering Conference 7 September 2016. Politeknik Caltex Riau Pekanbaru.

Sinaga, P., 2008. Menuju Pasar Yang Berorientasi Pada Perilaku Konsumen. Bahan pada pertemuan nasional tentang pengembangan pasar tradisional oleh Koperasi dan UKM, tanggal 12-14 Agustus. Bandung. 